\title{
Cointegration of Major Stock Market Indices during the 2008 Global Financial Distress
}

\author{
Komlavi Elubueni Assidenou \\ School of Finance, Shanghai University of Finance and Economics \\ 369, Zhongshan Bei Yi Road, Blg 8, Room 324, 200083 Shanghai, P.R. China \\ E-mail: assidenou@gmail.com
}

Received: July 30, 2010 Accepted: August 19, 2010 doi:10.5539/ijef.v3n2p212

\begin{abstract}
This paper investigates the cointegration properties of major capital markets indices during the September, 2008 / August, 2009 episode of the financial and banking crises originated in U.S markets. Based on daily closing prices of international stock markets indices, the analysis shows that three set of indices of economies (OECD group, Pacific group and Asia group) have at least one cointegrating vector. Contrary to former studies that concluded on the independencies of Asian markets, this paper reveals that during the deeper financial crisis period, Asian major markets indices were cointegrated. This finding suggests that local investors in Asian capital markets cannot avoid any influence from outside capital markets even if some local markets are still entirely not opened to international investors.
\end{abstract}

Keywords: Cointegration, Financial Integration, Stock Markets Indices, Financial Crisis

\section{Introduction}

International financial markets development in the past decades has been characterized by many changes in policy regarding the restrictions on cross-border transactions, investments, and exchange control. Many restrictions have been eliminated leading to a strong reform of international capital markets' structures. National stock exchanges have seen their places invaded by many outside investors who were seeking better returns and diversification of risks of their portfolio. This internationalization of financial markets operations has led to an amount of research that focused on the benefits of the liberalization of cross-border financial operations. While benefits of the liberalization have been advocated by many authors as a mean for optimal diversification and risk sharing, some studies show negative point of view on this issue. In a study on the volatility and links between national stock markets, Mervyn King and others (1994) develop an argument against the integration of financial markets. They found that the price of risk is not common across countries and confirm the null hypothesis of no integration of capital markets. In the same way, Young Song (1993) argued that opening or integration of capital can result in welfare deterioration. However, the real world facts did not taken these opinions in mind, and following deregulations policies, other authors have studied the potentially increasing process of financial markets integration at the international level.

In effect, the liberalization of capital markets can promote market integration, which has important investment and policy implications. The amount of benefits stemming from international diversification would be different under internationally segmented markets than under integrated markets. It cannot be subtracted the fact that increasing integration and openness must lead to more volatility and exposure to a foreign country economic or financial disturbances. Then the transmission of market turbulence is likely to be greater if international financial markets are integrated. Furthermore, the pricing of assets in segmented markets is different from that in integrated capital markets. Taking into account these opposite views on the benefits/costs of financial integration, it seems important to determine whether international financial markets have become more integrated. While previous works have used mid-1980 datasets to find that capital markets were segmented [see for example Errunza and Losq (1985) and Jorion and Schwartz (1986)], 1990's works have shown increasing integration of financial markets in industrially developed OECD countries [see Goldstein and Mussa (1993) for a survey and discussion on the integration of world capital markets]. (Note1)

A traditional approach to ascertain changes in the degree of integration among international stock markets is to study changes in the correlations among international stock market prices over time. An increase in correlation is often taken as evidence of an increase in the degree of market integration and a higher tendency that shock in one country is transmitted to another. However, such an approach is not the most informative one since correlations are determined by short-term trading noises as well as by long term fundamental relationship among the markets. Short-term variations in prices can obscure the image of the long-run relationship among the markets induced by the growing liberalization. To solve this problem, it is useful to look at the long-run relationship among international 
financial markets based on the idea of cointegration introduced by Engle and Granger (1987).

According to Engle and Granger (1987), if two random walks price series have a long-run equilibrium relationship, they cannot drift apart indefinitely. The deviation from their long-run equilibrium relationship must be stationary with zero mean. In this case, the two price series are said to be cointegrated. This idea can be extended into a multivariate setting. If there is really a long-run equilibrium relationship among non-stationary price series, then there is a combination of the non-stationary price series which is stationary. The methodology based on the multivariate cointegration [Johansen (1988)] determination has been employed by many researchers to test for the cointegration properties of many economic and financial variables. Mills and Mills (1991) considered the issue of cointegration between four international bond markets (U.S, UK, Germany and Japan) by using daily observations on the redemption yields. They found no cointegration between international bonds markets and concluded that these markets have shown relative independencies of one another after running the variance decomposition and impulse-response tests on these variables. Mishra (2002) investigates international integration of India's domestic financial markets. The findings suggest a correlation between NASDAQ index and the Bangalore Stock Exchange (BSE) index in terms of influences of the former on the latter. Mishra (2002) however found no cointegrating vector between these two variables. As specified in the theory, bivariate cointegration analysis can lead to incorrect inference since equilibrium relationship is multivariate in nature. Using daily closing prices from January 1995 to December 1999, Chang (2002) explores whether there exist any long-run benefits from equity diversification for investors who invest in two Chinese stock markets (Shanghai and Shenzhen). Using the multivariate Trace statistic, Harris-Inder approach and the Johansen method, he finds that these two stock markets are not pair-wise cointegrated. He concluded that there exist potential for investors to diversify risk in these two markets. Chang's (2002) approach is different from that I am discussing in this paper where the analysis of Shanghai Stock Exchange Composite index reaction is tested through its plausible long-run equilibrium relationship with other major financial markets in East-Asia. Nath and Verma (2003) undertake a study of the long-run relationship between stock indices of India, Singapore and Taiwan. By employing bivariate and multivariate cointegration analysis, they found no cointegration between those markets. It is worth noting that analyses above have been made in a normal context of economic and financial activities, so the results obtained at that time were reflecting the less integration of those marketplaces to the international financial sphere. This paper prompts to look at the change in behavior of major indices at the time of the 2008/2009 financial distress at the international level. Sheng and Tu (2000) have undertaken a similar analysis by trying to examine equity prices of Taiwan, Malaysia, Thailand, South-Korea, the Philippines, Indonesia, China, the U.S, Australia, Singapore, Japan and Hong-Kong before and during the period of 1998 Asian financial crisis. Daily closing price indices of the respective national stock exchanges were collected from July 1, 1996 to June 30, 1999 and the multivariate Johansen cointegration test was run to provide evidence that support the existence of co-integrational relationship among the national stock indices during, but not before, the period of 1998 Asian financial crisis. Their findings asserted a strong relationship among South-East Asia and the leading role of the U.S market.

While this paper's motivation is in the same way as it analyses the cointegration between major international stock exchanges indices during the asset prices' trough of the 2008-2009 financial crisis, it differs from that of Sheng and Tu by looking for the cointegration relationship when the U.S capital markets are the sources of the global financial distress. The analysis covers the period when the crisis hits its peak in September 2008 with the failure of major financial institutions: Lehman Brothers, Merrill Lynch, Fannie Mae, Freddie Mac, Washington Mutual and AIG, among others. Furthermore, the reaction of international financial markets relative to the U.S indices behavior during this period is highlighted. Finally, I tried to split the global financial system into three groups of stock exchange indices, according to the latest development of financial flows around the world and the crucial role that emerging Asian financial markets are playing in this context: OECD group, Pacific group and Asia group. The rest of the paper is organized as follow. The next section reviews the literature on financial integration. Section 3 presents the sampling technique and describes data and variables under consideration. Section 4 introduces the methodology while section 5 presents the empirical results. I discuss the main findings and conclude the paper at section 6 .

\section{Literature review}

Financial globalization effects have been subject to many studies. Theoretical developments and empirical literature do not show identical outcomes. Broadly speaking, empirical studies' findings are mixed and do not clearly restate the theory predictions. Here I provide an overview of the existing theory and some empirical evidences on financial integration.

\subsection{Theory}

The new open-economy macroeconomics (NOEM) model pioneered by Obstfeld and Rogoff (1995) has become a standard framework for studying international macroeconomic issues, particularly on globalization effects. NOEM models provide a basis to study the implications of the integration of international financial markets for 
macroeconomic fluctuations. Sutherland (1996) has shown how the standard NOEM can be extended to analyze the implications of financial integration for the impact monetary, fiscal, and productivity shocks on macroeconomic fluctuations. Buch and al. (2005) modified Sutherland's version of the NOEM model by assuming that households' consumption choices reflect habit formation. To capture the autonomous financial market shocks on business cycle, they incorporate a risk-premium shock and build into the model policy reaction functions. This allows the robustness of the link between financial openness and business cycle volatility with respect to the specification of the policy regime. The simulation results obtained from their paper suggest an unstable relationship between financial openness and business cycle volatility. Since financial openness implies an increasing tendency to the integration to world's financial markets, it is critical to look at the link between financial integration and volatility. Financial integration is viewed as a way that permits higher capital mobility, perfect risk sharing and consumption smoothing in a globalized marketplace. However, financial integration benefits are not clear regarding the macroeconomic performance of both developed and emerging economies (Obstfeld and Rogoff [2004]). While Bekaert, Harvey and Lundblad (2004) show that financial liberalization is associated with lower consumption volatility in developed countries, they fail to establish the same results in emerging markets. Kose and al. (2006) argue that more financial integration must facilitate a better risk sharing which is associated with a greater specialization among developed economies and across regions of developed economies. A strand of the recent literature advocates the diversification effect that characterizes financial integration but others state that enhanced specialization based on comparative advantage considerations could make countries more vulnerable to industry-specific shocks (Kose, Prasad and Terrones [2004]). The relationship between financial openness and output volatility could also be affected by some features of developing countries that make them more vulnerable to external shocks. The limited diversification of their exports and imports could make them susceptible to terms of trade and foreign demand shocks. Another prediction of the theory is the co-movement of cross country economic and financial aggregates in the presence of increased financial integration. In theory, the effect on cross-country correlations of output growth is uncertain, since it depends on the nature of shocks and specialization patterns. But consumption growth cross-country correlations are strong in explaining the degree of financial integration. Since in portfolio optimization models consumption smoothing is crucial for agents, capital markets indices also may reflect the effects of a change in financial openness. Thus, deeper integration might lead to a co-movement of consumption across countries. Empirical studies somewhat try to ascertain theory predictions concerning the behavior of economic and financial variables on the path of financial integration.

\subsection{Empirical studies}

Empirical evidence on financial integration based on the theoretical models developed in the above sub-section has been inconclusive in the three dimensions of growth, volatility and co-movement. Prasad, Rogoff, Wei and Kose [2003]) document country specific experiences during 1980-2000, suggesting that a higher level of financial integration is not a necessary condition to attain high growth. For example, China and India achieved high growth rates despite limited and selective capital account liberalization. Mauritius and Botswana had strong growth rates despite being relatively closed to financial flows. Another example includes Jordan and Peru who became relatively opened to foreign capital flows during this period but suffered economic contraction. Crises episodes receive more attention and the opinion is generally convincing that volatility is associated with openness. But it is worthwhile noting that crises are just particularly sharp manifestations of the more general phenomenon of macroeconomic volatility. For instance, there is trend decline in macroeconomic volatility in most of the major industrial countries since the mid-1980s (Doyle and Faust [2005]), although this decline reasons are still a matter of debate in the literature. However, number of papers using a variety of regression models, different country samples and, time period lead to a conclusion that there is no systematic empirical link between financial openness and output volatility, which is consistent with the theory prediction. Despite the difficulty to attest a potential linkage between financial integration and economic variables behavior, some papers have used statistical properties to analyze the effects of financial integration. Since world's capital markets indices reflect the intensity of capital flows between countries, it is crucial to work on different financial markets indices and show up potential explanations of their correlations. This is a realistic application of international finance assumptions and such a methodology must provide further insights on financial openness of economies. Pretarius (2002) made an empirical estimate about cross-section and time-series models to determine the fundamental factors that influence the correlation and evolvement of the correlation between emerging stock markets. Data from 10 emerging stock markets, namely Argentina, Brazil, China, Greece, India, Korea, Malaysia, Mexico, South-Africa and Turkey, were used. The results showed that only the extent of bilateral trade and the industrial production growth differential matter. Brooks and Negro (2002) tried to explore whether the rise in co-movement across national stock markets since 1990 was driven by global integration. Their tests provided evidence in favor of the 2000s stock market bubble to strengthen the rise in co-movement across national stock markets. Again Brooks and Negro (2003) attempted to investigate the empirical link between international stock market co-movement and the degree to which firms operate internationally. By measuring the betas of stock returns with respect to global, country and industry specific shocks, 
they found a strong and highly significant link between those betas and firm-level variables that measure international diversification.

Empirical studies built on stock markets variables had provided more incentives to pursue applications of international finance research challenges by using statistical techniques. In particular, the cointegration approach to measure market integration can be considered as a straightforward technique. This approach confirms co-integration among a set of series when there exists a long-run equilibrium relationship between them. Stock market integration implies cointegration between prices in two given markets. If two series are cointegrated, there exists an error correction mechanism to explain the short-run deviations of prices from their respective equilibrium values. This paper prompts to use this technique to investigate the behavior of major stock prices during the financial crisis episode of September 2008 through August 2009 on daily basis.

\section{Sample, Data and Variables}

The empirical work is based on daily closing prices from September 2, 2008 to August 31, 2009 of the stock markets indices of the United States (S\&P500), France (CAC40), Germany (DAX), United Kingdom (FTSE), Sweden (OMXS), Japan (NIKKEI), Hong-Kong SAR (HANG SENG), New Zealand (NZ50), South Korea (KS11), China Mainland (Shanghai Stock Exchange Composite - SSEC) and China Province Taiwan (Taiwan Composite - TSEC). The data on daily stock markets indices were downloaded from the Yahoo Finance website (http://finance.yahoo.com). All prices were transformed and converted into U.S dollars in order to harmonize different prices in one currency unit. Data on exchange rates were obtained from the U.S Federal Reserve website which displays working days exchange rates between major currencies. The analysis is based on the logarithm of the stock price series in U.S dollars.

The sample period choice was motivated by the fact that it's during September 2008 that the major financial trough has occurred with the failure of Lehman Brothers. The end of $3^{\text {rd }}$ quarter 2008 was characterized by huge disturbances in major financial markets, in particular in U.S, Europe and Asia where stock exchanges indices felt dramatically at historical levels. From that period on, governments had taken measures to ensure the stability of the financial system until the end of 2009. But at that time, the overall global economy does not recover since financial crisis impacts on real economic variables such us GDP growth, inflation and unemployment (among others) were higher.

I first test for unit root in each price series based on the Augmented Dickey-Fuller test. The test results are reported in Table 1 in the Appendix-1. All results suggest that all series are non-stationary, so they potentially contain at least one root. The null hypothesis of a unit root can in no case be rejected at the $5 \%$ level.

Since the stock market indices of each country is found to be non-stationary according to the above results, I undertake the second stage of the work by looking at the plausibly long-term equilibrium relationship between the stock markets indices of the countries included in the sample. Specifically I test whether there are some linear combinations of the series. The test employed is Johansen's Trace and Max-eigenvalues.

In order to better understand the cointegration relationship that can survive in the set of stock markets indices, I run three different cointegration tests on the set of:

1. All stock markets indices of country-members of the Organization for Economic Co-operation and Development (OECD) - U.S, UK, France, Germany, Japan, Sweden - under consideration in this study. I denote this set as the OECD group.

2. All stock markets indices of U.S, Japan, Hong-Kong SAR, New-Zealand, South-Korea and Taiwan. I denote this set as the Pacific group.

3. All stock markets indices of Japan, China Mainland, Hong-Kong SAR, South Korea and Taiwan. I denote this set as the East-Asia group.

\section{Methodology}

The cointegration study depends on the non-stationarity of the stock markets prices of the sample. The first exercise is to test for a unit root in each price series, the second is to test for the cointegration between variables of the system of stock markets prices.

\subsection{Unit root tests}

To test for a unit root, the method employed was that of Dickey-Fuller (1979) where the basic objective is to examine the null hypothesis that $\varnothing=1$ in the following equation:

$$
\mathrm{Y}_{\mathrm{t}}=\varnothing \mathrm{Y}_{\mathrm{t}-1}+\mathrm{u}_{\mathrm{t}}
$$

against the one-side alternative $\varnothing<1$. Thus the hypotheses of interest are $\mathrm{H}_{0}$ : series contains a unit root versus $\mathrm{H}_{1}$ : series is stationary. In practice however, the following regression is employed rather than (1):

$$
\Delta \mathrm{Y}_{\mathrm{t}}=\varphi \mathrm{Y}_{\mathrm{t}-1}+\mathrm{u}_{\mathrm{t}}
$$


so that a test of $\varnothing=1$ is equivalent to a test of $\varphi=0 \quad(\varnothing-1=\varphi)$.

Dickey-Fuller (DF) tests can be conducted allowing for an intercept, or an intercept and deterministic trend, or neither in the test regression. The model for the unit root test in each case is:

$$
\mathrm{Y}_{\mathrm{t}}=\varnothing \mathrm{Y}_{\mathrm{t}-1}+\mu+\lambda \mathrm{t}+\mathrm{u}_{\mathrm{t}}
$$

The test can also be written by subtracting $\mathrm{Y}_{\mathrm{t}-1}$ from each side of the equation, as:

$$
\Delta \mathrm{Y}_{\mathrm{t}}=\varphi \mathrm{Y}_{\mathrm{t}-1}+\mu+\lambda \mathrm{t}+\mathrm{u}_{\mathrm{t}}
$$

In a paper published in 1981, Dickey and Fuller provide a set of additional test statistic and their critical values for a joint tests of the significance of the lagged $\mathrm{Y}$, and the constant and trend terms. However the tests statistics for the original DF tests are defined as:

$$
\text { test statistic }=\frac{\widehat{\varphi}}{\widehat{\mathrm{SE}}(\widehat{\varphi})}
$$

The null hypothesis of a unit root is rejected in favor of the stationary alternative in each case the test statistic is more negative than the critical value.

To correct for over-sizing in the test, DF find the solution to "augment" the test using $p$ lags of the dependent variable.

The alternative model is:

$$
\Delta \mathrm{Y}_{\mathrm{t}}=\varphi \mathrm{Y}_{\mathrm{t}-1}+\sum_{\mathrm{i}=1}^{\mathrm{p}} \alpha_{\mathrm{i}} \Delta \mathrm{Y}_{\mathrm{t}-\mathrm{i}}+\mathrm{u}_{\mathrm{t}}
$$

The lags of $\Delta \mathrm{Y}_{\mathrm{t}}$ soak-up any dynamic structure in the dependent variable to ensure that $\mathrm{u}_{\mathrm{t}}$ is not autocorrelated. This test is known as the "Augmented Dickey-Fuller" (ADF) test and is still conducted on $\varphi$, and the same critical values from DF tables are used for the decision rule.

\subsection{Cointegration test}

To test for the cointegration between stock market indices variables, the Johansen (1988) method based on Vectors Autocorrelations (VAR) is used. Consider a set of $g$ variables $(g \geq 2)$ that are $\mathrm{I}(1)$ and which are assumed to be cointegrated. A VAR with $k$ lags containing these variables could be set-up:

$$
\mathrm{Y}_{\mathrm{t}}=\beta_{1} \mathrm{Y}_{\mathrm{t}-1}+\beta_{2} \mathrm{Y}_{\mathrm{t}-2}+\cdots+\beta_{\mathrm{k}} \mathrm{Y}_{\mathrm{t}-\mathrm{k}}+\mathrm{u}_{\mathrm{t}}
$$

gxl gxg gxl gxggxl gxggxl gxl

In order to use the Johansen test, the VAR (7) above needs to be turned into a vector error correction model (VECM) of the form:

$$
\Delta \mathrm{Y}_{\mathrm{t}}=\prod \mathrm{Y}_{\mathrm{t}-\mathrm{k}}+\Gamma_{1} \Delta \mathrm{Y}_{\mathrm{t}-1}+\Gamma_{2} \Delta \mathrm{Y}_{\mathrm{t}-2}+\cdots+\Gamma_{\mathrm{k}-1} \Delta \mathrm{Y}_{\mathrm{t}-(\mathrm{k}-1)}+\mathrm{u}_{\mathrm{t}}
$$

where $\Pi=\left(\sum_{i=1}^{\mathrm{k}} \beta_{\mathrm{i}}\right)-\mathrm{I}_{\mathrm{g}}$ and $\Gamma_{\mathrm{i}}=\left(\sum_{\mathrm{j}=1}^{\mathrm{i}} \beta_{\mathrm{j}}\right)-\mathrm{I}_{\mathrm{g}}$

The test for cointegration between the Ys is calculated by looking at the rank of the $\Pi$ matrix via its eigenvalues. The eigenvalues, denoted $\lambda_{\mathrm{i}}$ are put in ascending order $\lambda_{1} \geqq \lambda_{2} \geqq \ldots \lambda_{\mathrm{g}}$. If $\lambda_{\mathrm{s}}$ are unit roots, in this context they must be less than 1 in absolute value and positive and $\lambda_{1}$ will be the largest i.e the closest to one while $\lambda_{\mathrm{g}}$ will be the smallest. If the variables are not cointegrated, the rank of $\Pi$ will not be significantly different from zero, so $\lambda_{\mathrm{i}} \approx 1$ for any $\mathrm{i}$. There are two tests statistics for the cointegration under the Johansen approach:

$$
\begin{gathered}
\text { The Trace: } \lambda_{\text {trace }}(r)=-\mathrm{T} \sum_{\mathrm{i}=\mathrm{r}+1}^{\mathrm{g}} \ln \left(1-\widehat{\lambda_{1}}\right) \\
\text { and the Max-eigenvalue: } \lambda_{\max }(\mathrm{r}, \mathrm{r}+1)=-\mathrm{T} \ln \left(1-\widehat{\lambda_{\mathrm{r}+1}}\right)
\end{gathered}
$$

where $\mathbf{r}$ is the number of cointegrating vectors under the null hypothesis.

Johansen and Juselius (1990) provide critical values for the two statistics. If the test statistic is greater than the critical value from Johansen's tables, reject the null hypothesis that there are $r$ cointegrating vectors in favor of the alternative that there are $\mathrm{r}+1$ (for $\lambda_{\text {trace }}$ ) or more than $\mathrm{r}$ ( for $\lambda_{\max }$ ).

\section{Results Analysis}

The results are presented in Table 2 (see the Appendix-1). For each group, the table shows the results for the Trace and Max-eigenvalue statistics respectively. The second column in each case presents the ordered eigenvalues, the third column the test statistic, the fourth column the critical value and the final column the $p$-value. For example, examining the trace statistic of the OECD group, the first row after the headers, the statistic of 137.8411 exceeds the critical value of 95.75366 and so the null hypothesis of no cointegration vectors is rejected. If one moves to the next row, the test statistic (83.65478) again exceeds the critical value so that the null of no cointegrating vectors is also rejected. But the third row's test statistic does not exceed the critical value; in this case, the null of no cointegrating vector cannot be rejected. 
In the OECD group case, Johansen's test of cointegration output shows that the null hypothesis of no cointegration is rejected. There are at most two cointegrating vectors for the OECD group and this suggest there are long run equilibrium relationships between the stock market indices of this group of countries. Trace and Max-eigenvalue test statistics indicate two cointegrating vectors at 5\% level. The absence of conflicting results of these two test statistics is significant of the consistency of the results.

In the Pacific group case, the null hypothesis of no cointegration between the stock market indices is also rejected by the same reasoning. There exist at most two cointegrating vectors for the Pacific group and this suggest that there are long-run equilibrium relationships between the stock market indices of this group of countries. The Trace test statistic indicates two cointegrating vectors at 5\% level while the Max-eigenvalue test statistic indicates one cointegrating vector at $5 \%$ level. In any case, there is at least one long-run equilibrium relationship between the stock markets indices of the Pacific group

In the East-Asia group case, the null hypothesis of no cointegration between the stock markets indices is rejected. Here however, there is only or, at most one cointegrating vector among the stock market indices of the East-Asia area. The Trace and Max-eigenvalue test statistics indicate together one cointegrating vector at $5 \%$ level.

\section{Discussion and Concluding Remarks}

Daily observations between series of international stock markets indices during the trough period of the financial crisis seem confirm the fact that market efficiency during bad times is more pronounced than in normal times. These situations have some implications regarding the economic or financial leadership, the investment strategies and the structure of capital markets.

The U.S economic and financial conditions may impact in the long-run the performance of other markets because the increasing globalization favors the transmission effect on either major or emerging markets. While in the 1990 the market and economic integration was more visible between the U.S and Western-Europe economies, recent developments show other parts of the world, especially the East-Asia zone benefit large amounts of foreign direct investments and portfolio investments from U.S and Europe. On the other side, East-Asian countries' production is mainly exported to the U.S and Europe. Since the overall economic performance is mainly linked to the Western's aggregate consumption demand, any economic cycle at the Western side has effects on East-Asian economies. The 2007/2008 U.S financial distress may then impact, on one way or another capital markets values in the emerging East-Asia. The leading power of U.S economy in the Pacific zone is still important in this regard. In the East-Asia group, Japan and China economies play crucial roles when we refer to data on referenced sources like the International Monetary Fund's reports. Though this paper did not taken into account the stock market of Singapore, which is an important one in the region, the cointegration relationship between capital markets in the East-Asia region is a stronger one. Even markets that are not opened to outside investors react to news or economic and financial conditions occurring in the Japanese or Hong-Kong SAR markets. The Shanghai Stock Exchange (see Appendix-2's graphs) shows the co-movement of its SSEC index during this period with the major international stock markets indices. The deterioration of the foreign demand for China products during that period of time has had the same impact on financial assets performance in Mainland China financial markets. The same observation can be made about the Korean KS11 composite index which shows strong negative values at that time.

For investors, the above results do suggest that there is no way to hedge against a deterioration of financial conditions in any area during a crisis time. Although the 1998 Asian financial crisis had affected negatively major stock exchanges in the region as confirmed by former studies, the recent 2008 crisis has shown some new trends in the integration of Asian capital markets to the international financial marketplace. The Shanghai Stock Exchange, according to the co-integration results shown in the appendix of this paper is proven to have a long-term equilibrium with opened markets indicators. This is also a signal that Chinese investors, for instance can no longer be protected against any outside negative influence by arguing that the national stock markets are closed to outside investors. The Chinese economy is driven by outside factors, especially the American and European aggregate demand for manufactured products, so this link may govern the pattern of exports companies' assets on the stocks exchange, and then govern the composite index. The same analysis can be made regarding the volume of Japanese companies investments in mainland China that let its stock markets react to any movement in the Nikkei index.

It might be useful to wonder if this increasing integration of international financial markets confirms interdependencies of economies and, then all instantaneous reactions of markets are not linked to the increasing efficiency of information processing within financial markets whatever there are opened or not to foreign investors. This is left as a future research task in the international finance and capital markets fields.

\section{References}

Bekaert, Harvey \& Lundblad. (2004). Growth Volatility and Financial Liberalization, NBER Working Paper 10560, National Bureau of Economic Research, Inc.

Brooks, Chris. (2008). Introductory Econometrics for Finance, 2nd edition, Cambridge University Press. 
Brooks, R. \& Negro. (2002). The rise in comovement across national stock markets: market integration or IT bubble?, Working Paper, 2002-17a, Federal Reserve Bank of Atlanta.

Brooks, R. \& Negro. (2003). International Stock Returns and Market Integration: a regional perspective. IMF Working Papers 02/202, International Monetary Fund.

Brooks, R. \& Negro. (2003). Firm Level Evidence on International Stock Market Comovements, Working Paper, March 2003, Federal Reserve Bank of Atlanta.

Buch, C., J. Dopke \& C. Pierdziock. (2005). Financial Openness and Business Cycle Volatility, Journal of International Money and Finance, vol.24, pp. 744-65. doi:10.1016/j.jimonfin.2005.04.002, http://dx.doi.org/10.1016/j.jimonfin.2005.04.002

Chang, Tsangyao. (2002). Long-run Benefits from Equity Diversification in two Chinese Share Markets: B-share from Shanghai and Shenzhen Stock exchanges, The Indian Journal of Economics LXXXII, 303-310

Doyle, B. \& J. Faust. (2005). Breaks in Variability and Co-movement of G-7 Economic Growth, Review of Economics and Statistics, vol.87, No.4, pp. 721-40. doi:10.1162/003465305775098134, http://dx.doi.org/10.1162/003465305775098134

Engle, R., \& C.W.J. Granger. (1987). Cointegration and Error Correction: Representation, Estimation, and Testing, Econometrica, Vol.55. (No2,1987).pp.251-76.

Errunza, V., \& E. Losq. (1985). International Asset Pricing under Mild Segmentation: Theory and Test, Journal of Finance, vol.40. (No.1, 1985). pp. 105-24

Goldstein, M. \& M.Mussa. (1993). The Integration of World Capital Markets, Working Paper. (Washington: International Monetary Fund, 1993)

Johansen, S.(1988). Statistical Analysis of Cointegration Vectors, Journal of Economics and Dynamic Control, Vol.12(1988).pp.231-54. doi:10.1016/0165-1889(88)90041-3, http://dx.doi.org/10.1016/0165-1889(88)90041-3

Jorion, P., \& E. Schwartz. (1986). Integration vs. Segmentation in the Canadian Stock Market, Journal of Finance, vol.41. (No3,1986). pp.603-13

Kose,M.A., E. Prasad, K. Rogoff \& S-J Wei. (2006). Financial Globalization: a reappraisal, IMF Working Paper $06 / 189$

Mervyn King, E. Sentana \& S. Wadhwani. (1994). Volatility and Links between National Stock Markets, Econometrica, Vol.62,N 4 Jul 1994);pp 901-933. doi:10.2307/2951737, http://dx.doi.org/10.2307/2951737

Mills, T.C., \& A.G. Mills. (1991). The International Transmission of Bond Market Movements, Bulletin of Economic Research 43, 273-82. doi:10.1111/j.1467-8586.1991.tb00496.x, http://dx.doi.org/10.1111/j.1467-8586.1991.tb00496.x

Mishra, Arun K. (2002). International Financial Integration of Domestic Financial Markets: A study of India, The ICFAI Journal of Applied Finance 8(2).5-15.

Nath, G.C., \& S.Verma. (2003). Study of Common Stochastic Trend and Cointegration in the Emerging Markets: A Case Study of India, Singapore \& Taiwan, Research Paper, NSE India

Obstfeld, M. \& K. Rogoff. (2004). Foundations of International Macroeconomics, Cambridge, Massachussetts: MIT Press.

Obstfeld, M. \& K. Rogoff. (1995). Exchange rate dynamics redux, Journal of Political Economy 103, 624-60, 1995. doi:10.1086/261997, http://dx.doi.org/10.1086/261997

Pretarius, E. (2002). Economic Determinants of Emerging Stock Market Interdependence, Emerging Markets Review. (March). 84-105. doi:10.1016/S1566-0141(01)00032-2, http://dx.doi.org/10.1016/S1566-0141(01)00032-2

Sheng, H.C., \& A.H. Tu. (2000). A Study of Cointegration and Variance Decomposition among National Equity Indices Before and During the Period of the Asian Financial Crisis, Journal of Multinational Financial Management 10, 345-365. doi:10.1016/S1042-444X(00)00034-7, http://dx.doi.org/10.1016/S1042-444X(00)00034-7

Sutherland, A. (1996). Financial Market Integration and Macroeconomic Volatility, Scandinavian Journal of Economics 98, 129-539. doi:10.2307/3440882, http://dx.doi.org/10.2307/3440882

Young Song. (1993). Increasing Returns and the Optimality of Open Capital Markets in a Small Growing Economy, International Economic Review, Vol. 34, No. 3. (Aug., 1993). pp.705-713. doi:10.2307/2527189, http://dx.doi.org/10.2307/2527189

Notes

Note 1. OECD is the Organization for Economic Cooperation and Development. 
Table 1. ADF unit root tests

\begin{tabular}{|l|l|l|l|}
\hline Indices & ADF test statistic & Test critical value & Observations \\
\hline S\&P500 & -2.656593 & -2.872998 & One unit root \\
\hline CAC40 & -2.702104 & -2.873093 & One unit root \\
\hline DAX & -2.392686 & -2.872998 & One unit root \\
\hline FTSE & -2.502176 & -2.873142 & One unit root \\
\hline NIKKEI & -1.96821 & -2.873701 & One unit root \\
\hline OMXS & -1.957306 & -2.87339 & One unit root \\
\hline HANG SENG & -1.691298 & -2.873289 & One unit root \\
\hline NZ50 & -1.64165 & -2.873093 & One unit root \\
\hline TSEC & -1.100107 & -2.873648 & One unit root \\
\hline SSEC & -0.859762 & -2.873755 & One unit root \\
\hline KS11 & -1.578028 & -2.873289 & One unit root \\
\hline
\end{tabular}

Table 2. multivariate cointegration results

Panel 1: OECD group cointegration tests results

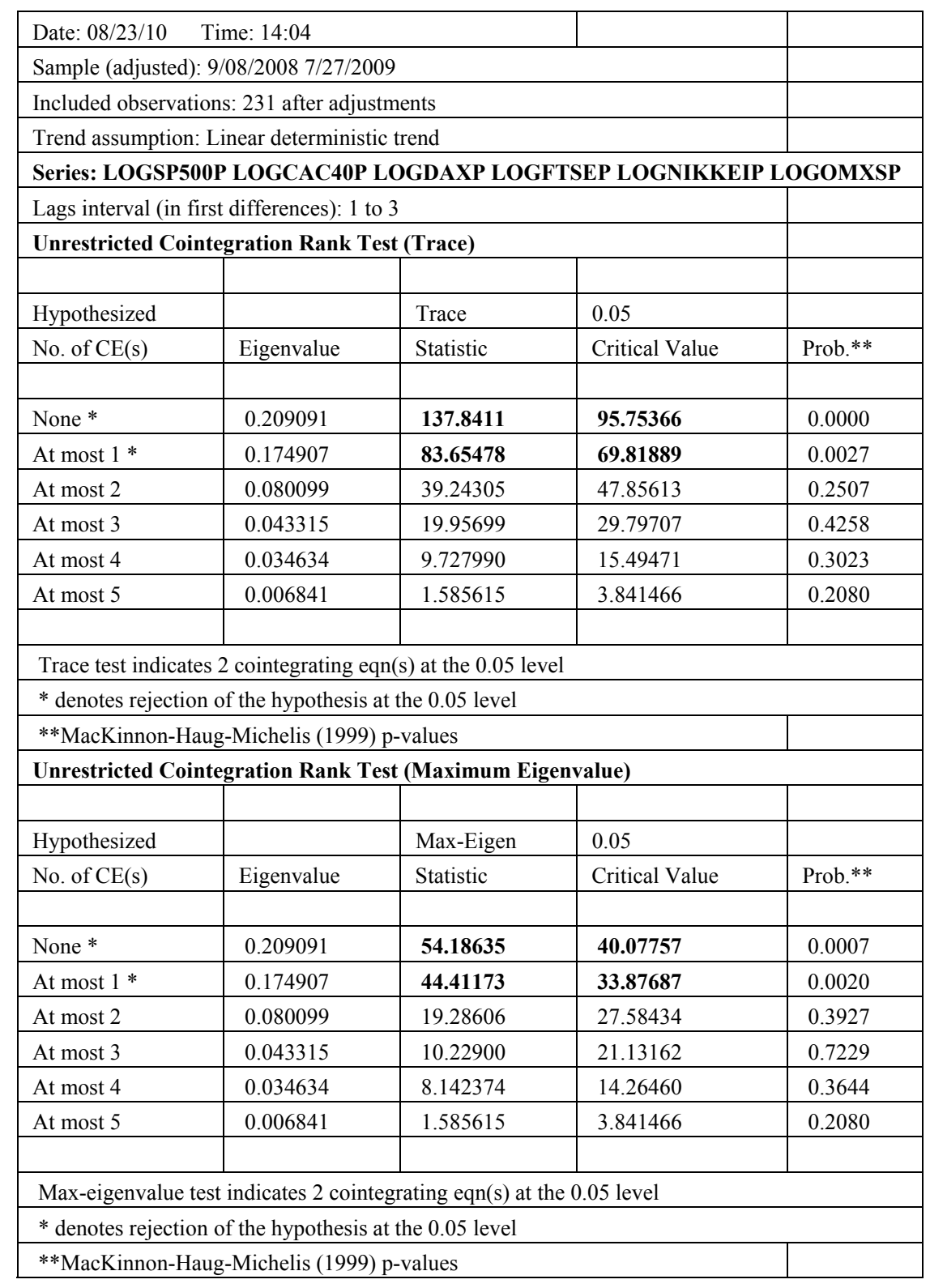


Panel 2: Pacific group cointegration tests results

\begin{tabular}{|c|c|c|c|c|}
\hline \multirow{2}{*}{\multicolumn{5}{|c|}{$\begin{array}{l}\text { Date: } 08 / 24 / 10 \quad \text { Time: } 11: 15 \\
\text { Sample (adjusted): } 9 / 08 / 20087 / 27 / 2009\end{array}$}} \\
\hline & & & & \\
\hline \multicolumn{5}{|c|}{ Included observations: 231 after adjustments } \\
\hline \multicolumn{5}{|c|}{ Trend assumption: Linear deterministic trend } \\
\hline \multicolumn{5}{|c|}{ Series: LOGSP500P LOGNIKKEIP LOGHGSGP LOGNZ50P LOGKS11P LOGTSECP } \\
\hline \multicolumn{5}{|c|}{ Lags interval (in first differences): 1 to 3} \\
\hline \multicolumn{5}{|c|}{ Unrestricted Cointegration Rank Test (Trace) } \\
\hline Hypothesized & & Trace & 0.05 & \\
\hline No. of CE(s) & Eigenvalue & Statistic & Critical Value & Prob.** \\
\hline None* & 0.200157 & 121.6429 & 95.75366 & 0.0003 \\
\hline At most $1 *$ & 0.101529 & 70.05144 & 69.81889 & 0.0479 \\
\hline At most 2 & 0.072751 & 45.32030 & 47.85613 & 0.0849 \\
\hline At most 3 & 0.067729 & 27.87225 & 29.79707 & 0.0820 \\
\hline At most 4 & 0.033948 & 11.67181 & 15.49471 & 0.1734 \\
\hline At most 5 & 0.015862 & 3.693571 & 3.841466 & 0.0546 \\
\hline \multicolumn{5}{|c|}{ Trace test indicates 2 cointegrating eqn(s) at the 0.05 level } \\
\hline \multicolumn{5}{|c|}{ * denotes rejection of the hypothesis at the 0.05 level } \\
\hline \multicolumn{5}{|c|}{ **MacKinnon-Haug-Michelis (1999) p-values } \\
\hline \multicolumn{5}{|c|}{ Unrestricted Cointegration Rank Test (Maximum Eigenvalue) } \\
\hline & & & & \\
\hline Hypothesized & & Max-Eigen & 0.05 & \\
\hline No. of CE(s) & Eigenvalue & Statistic & Critical Value & Prob.** \\
\hline None * & 0.200157 & 51.59148 & 40.07757 & 0.0017 \\
\hline At most 1 & 0.101529 & 24.73114 & 33.87687 & 0.4034 \\
\hline At most 2 & 0.072751 & 17.44805 & 27.58434 & 0.5416 \\
\hline At most 3 & 0.067729 & 16.20043 & 21.13162 & 0.2134 \\
\hline At most 4 & 0.033948 & 7.978244 & 14.26460 & 0.3809 \\
\hline At most 5 & 0.015862 & 3.693571 & 3.841466 & 0.0546 \\
\hline \multicolumn{5}{|c|}{ Max-eigenvalue test indicates 1 cointegrating eqn(s) at the 0.05 level } \\
\hline \multicolumn{5}{|c|}{$*$ denotes rejection of the hypothesis at the 0.05 level } \\
\hline **MacKinno & -Michelis $(1$ & ralue & & \\
\hline
\end{tabular}


Panel 3: East-Asia group cointegration tests results

\begin{tabular}{|c|c|c|c|c|}
\hline \multicolumn{3}{|c|}{ Date: $08 / 24 / 10 \quad$ Time: $15: 10$} & & \\
\hline \multicolumn{4}{|c|}{ Sample (adjusted): 9/08/2008 7/24/2009 } & \\
\hline \multicolumn{4}{|c|}{ Included observations: 230 after adjustments } & \\
\hline \multicolumn{4}{|c|}{ Trend assumption: Linear deterministic trend } & \\
\hline \multicolumn{4}{|c|}{ Series: LOGNIKKEIP LOGHGSGP LOGSSECP LOGKS11P LOGTSECP } & \\
\hline \multicolumn{4}{|c|}{ Lags interval (in first differences): 1 to 3} & \\
\hline \multicolumn{4}{|c|}{ Unrestricted Cointegration Rank Test (Trace) } & \\
\hline Hypothesized & & Trace & 0.05 & \\
\hline No. of $\mathrm{CE}(\mathrm{s})$ & Eigenvalue & Statistic & Critical Value & Prob.** \\
\hline None * & 0.211291 & 95.87748 & 69.81889 & 0.0001 \\
\hline At most 1 & 0.071059 & 41.28528 & 47.85613 & 0.1798 \\
\hline At most 2 & 0.068788 & 24.33184 & 29.79707 & 0.1868 \\
\hline At most 3 & 0.018607 & 7.940046 & 15.49471 & 0.4718 \\
\hline At most 4 & 0.015616 & 3.620117 & 3.841466 & 0.0571 \\
\hline \multicolumn{5}{|c|}{ Trace test indicates 1 cointegrating eqn(s) at the 0.05 level } \\
\hline \multicolumn{5}{|c|}{$*$ denotes rejection of the hypothesis at the 0.05 level } \\
\hline \multicolumn{4}{|c|}{ **MacKinnon-Haug-Michelis (1999) p-values } & \\
\hline \multicolumn{5}{|c|}{ Unrestricted Cointegration Rank Test (Maximum Eigenvalue) } \\
\hline Hypothesized & & Max-Eigen & 0.05 & \\
\hline No. of $\mathrm{CE}(\mathrm{s})$ & Eigenvalue & Statistic & Critical Value & Prob.** \\
\hline None * & 0.211291 & 54.59221 & 33.87687 & 0.0001 \\
\hline At most 1 & 0.071059 & 16.95344 & 27.58434 & 0.5840 \\
\hline At most 2 & 0.068788 & 16.39180 & 21.13162 & 0.2028 \\
\hline At most 3 & 0.018607 & 4.319929 & 14.26460 & 0.8241 \\
\hline At most 4 & 0.015616 & 3.620117 & 3.841466 & 0.0571 \\
\hline \multicolumn{5}{|c|}{ Max-eigenvalue test indicates 1 cointegrating eqn(s) at the 0.05 level } \\
\hline \multicolumn{5}{|c|}{$*$ denotes rejection of the hypothesis at the 0.05 level } \\
\hline **MacKinnon & Michelis (195 & values & & \\
\hline
\end{tabular}




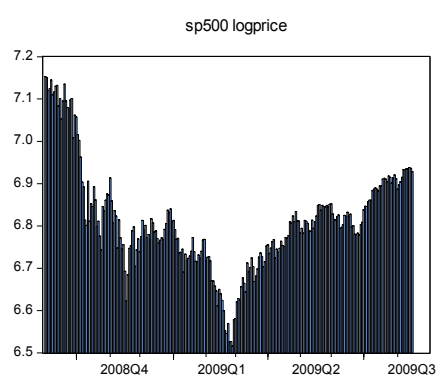

Figure 1. The S\&P $500 \log$ price movements from September 2, 2008 to August 31, 2009

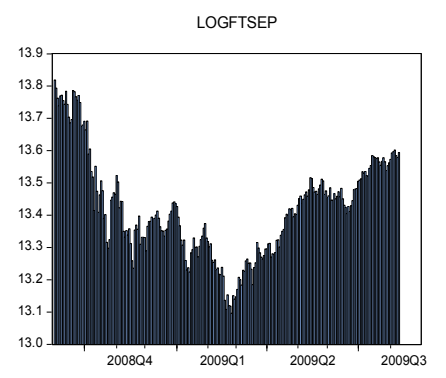

Figure 4. The FSTE log price movements from September 2, 2008 to August 31, 2009.

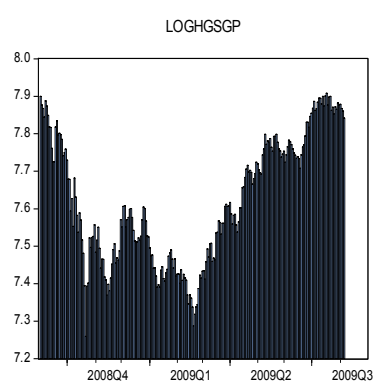

Figure 7. The HANG SENG log price movements from September 2, 2008 to August 31, 2009.

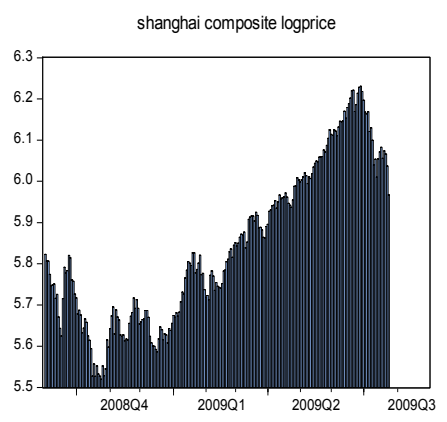

Figure 10. The SSE log price movements from September 2, 2008 to August 31, 2009.

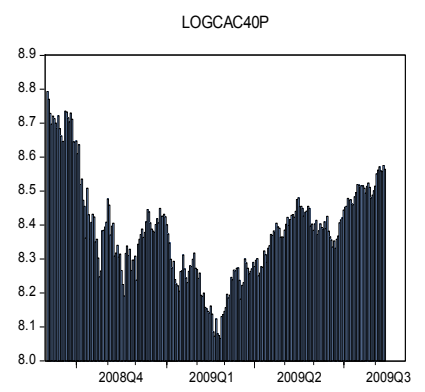

Figure 2. The CAC40 log price movements from September 2, 2008 to August 31, 2009.

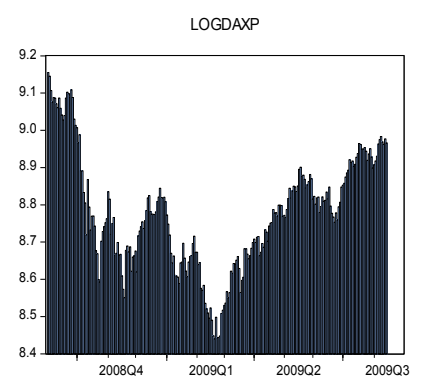

Figure 3. The DAX log price movements from September 2, 2008 to August 31, 2009.

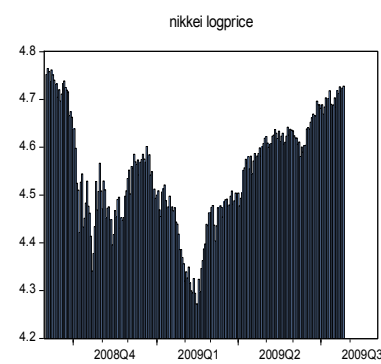

Figure 6. The NIKKEI log price movements from September 2, 2008 to August 31, 2009.
Figure 5. The OMXS log price movements from September 2, 2008 to August 31, 2009.

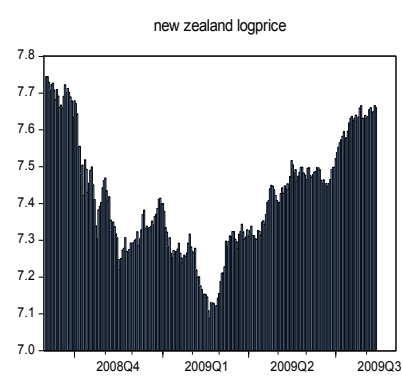

Figure 8. The NZ50 log price movements from September 2, 2008 to August 31, 2009.

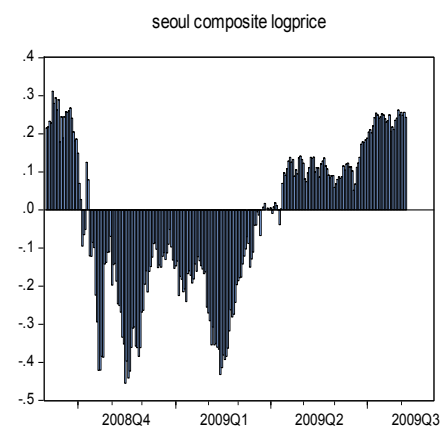

Figure 11. The KS11 log price movements from September 2, 2008 to August 31, 2009.

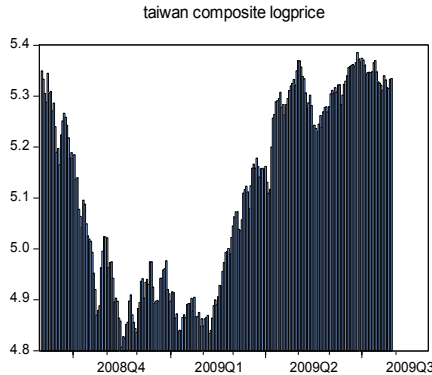

Figure 9. The TSEC log price movements from September 2, 2008 to August 31, 2009. 